\title{
Studies of a Hypomorphic Variant of Human C3
}

\author{
Chester A. Alper and Fred S. Rosen with the technical assistance of \\ LIIIIAN WATSON \\ From the Blood Grouping Laboratory and the Department of Medicine, \\ Children's Hospital Medical Center, and the Department of Pediatrics, \\ Harvard Medical School, Boston, Massachusetts 02115
}

\begin{abstract}
A в S T RAC T A hypomorphic electrophoretic variant of $\mathrm{C} 3$ with the mobility of $\mathrm{C} 3 \mathrm{~F}$ was found in the serum of a healthy man, his mother, and one of his two sons. Serum C3 concentrations were normal in these subjects as were hemolytic complement levels. Metabolic studies with radiolabeled purified $\mathrm{C} 3 \mathrm{FF}$ and $\mathrm{C} 3 \mathrm{SS}$ in the propositus suggested, but did not prove, that the variant $\mathrm{C} 3 \mathrm{~F}$ gene was hyposynthetic. The designation C $3 \mathrm{f}$ was therefore proposed for this allele.
\end{abstract}

\section{INTRODUCTION}

Extensive genetic polymorphism of the third component of complement, C3, has been found in man (1-4). Among Caucasians, two alleles, $C 3^{\mathrm{s}}$ with a gene frequency of approximately 0.77 and $C 3^{\mathrm{F}}$ with a frequency of 0.22 , control the synthesis of this protein in most individuals. Gene products are recognized by their relative electrophoretic mobilities in prolonged agarose-gel electrophoresis (3) or high voltage starch-gel electrophoresis (4). In heterozygotes, the concentration of the two allelic gene products is approximately the same. In one individual of apparent type C3 FS, the concentration of $\mathrm{C} 3 \mathrm{~F}$ was found to be distinctly less than that of $\mathrm{C} 3 \mathrm{~S}$, and studies of this subject and his family form the basis of this report.

\section{METHODS}

Serum. All sera were frozen promptly at $-80^{\circ} \mathrm{C}$ and thawed immediately before analysis.

Determination of $\mathrm{C} 3$ concentration. Concentration of $\mathrm{C} 3$ in serum was determined by both an electroimmunochemical (5) and a nephelometric technique (6) using monospecific rabbit or goat antisera to human C3 prepared by the method of Nilsson and Müller-Eberhard (7).

Electrophoretic methods. Prolonged electrophoresis of whole serum in agarose gel (8) was performed as described

A synopsis of this work was presented at a sectional meeting of the American Society for Clinical Investigation, May 1969, Atlantic City, N. J. (J. Clin. Invest 48: 2a. [Abstr.]). Received for publication 29 July 1970. previously (3), and the gels were either stained with Amido Black for $\mathrm{C} 3$ typing or were subjected to immunofixation $(9,10)$ with anti-C3, or were used for antigen-antibody crossed electrophoresis (11).

Metabolic studies with radioiodine-labeled C3. C3 was purified from the plasma of one subject who was C3 FF and one who was C3 SS. C3 FF was labeled with ${ }^{125 I}$ and C3 SS with ${ }^{181}$ I by the iodine monochloride technique (12). A mixture of these two labeled preparations was administered to each subject. The collection and processing of samples and methods of calculation have been described previously (13).

Subjects. The propositus, the living members of his family (Boe), and the normal subjects were all in excellent health.

\section{RESULTS}

The $\mathrm{C} 3$ in the serum of the propositus showed two bands on prolonged agarose-gel electrophoresis which corresponded to $\mathrm{C} 3 \mathrm{FS}$ in mobility. The concentration of $\mathrm{C} 3 \mathrm{~F}$ was, however, considerably lower than that of C3 S (Fig. 1). Identical C3 patterns were observed when his serum was examined by immunofixation after prolonged agarose-gel electrophoresis. Over 100 samples of other C3 FS sera examined in our laboratory have shown bands of approximately equal density. Patterns similar to that of the propositus were observed, however, when the sera of his mother and one of his two sons were studied. By elution of stained electrophoretic patterns, it was estimated that $40 \%$ of the total serum C3 had the mobility of $\mathrm{C} 3 \mathrm{~F}$, whereas $60 \%$ had the mobility of C3 S. A similar, but less accurate, estimate was obtained by antigen-antibody crossed electrophoresis, as shown in Fig. 2. In C3 FS patterns from six individuals, the average $F: S$ ratio was $52: 48$. Serum C3 concentrations of all the available family members are given in Table I and were normal. It, therefore, seems reasonable that the gene product with the mobility of $\mathrm{C} 3 \mathrm{~F}$ was reduced in concentration. Hence, the designation $\mathrm{C} 3 \mathrm{f}$ is proposed for this allele. As is evident from Table I, hemolytic complement was normal in all the family members. 


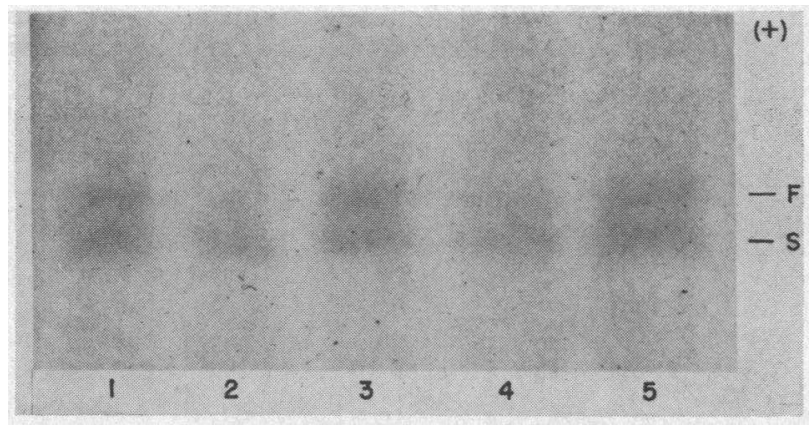

FIgURE 1 Prolonged agarose-gel electrophoresis showing the C3 area. Samples 1, 3, and 5 were C3 FS serum, whereas samples 2 and 4 were from the Boe family propositus and contained C3 $\mathrm{fS}$. The anode was at the top.

The results of the metabolic studies with labeled purified $\mathrm{C} 3 \mathrm{FF}$ and $\mathrm{C} 3 \mathrm{SS}$ in the $\mathrm{C} 3 \mathrm{fS}$ propositus, a C3 FF subject, and a C3 SS subject are given in Table II. The two C3 preparations gave closely similar fractional catabolic rates and extravascular: plasma pool ratios in all subjects, including the $\mathrm{C} 3 \mathrm{fS}$ individual. Synthesis rates for $\mathrm{C} 3 \mathrm{FF}$ were low in all subjects but particularly so in the $\mathrm{C} 3 \mathrm{fS}$ propositus. The serum concentration of $\mathrm{C} 3$ in the $\mathrm{C} 3 \mathrm{FF}$ subject was $90 \mathrm{mg} / 100 \mathrm{ml}$ (below the normal range of 96.9-203.7, as determined in our laboratory). The extravascular: plasma pool ratios for $\mathrm{C} 3 \mathrm{FF}$ were low in all subjects.

\section{DISCUSSION}

The present results provide evidence for a C3 allele with a gene product of the same electrophoretic mobility as $\mathrm{C} 3 \mathrm{~F}$ but occurring in lower concentration in serum than that of the other C3 allele. The inheritance of this trait, as is true of the other C 3 alleles, appears to be autosomal (since there is male to male transmission and there are male heterozygotes) and codominant. It is only possible to detect this form of $\mathrm{C} 3$ with certainty in the heterozygote and if an analogous gene, $\mathrm{C} 3 \mathrm{~s}$, occurs, it will be much more difficult to identify because of the higher frequency of $\mathrm{C} 3 \mathrm{~S}$ compared with other alleles in all populations studied to date.

TABLE I

C3 Concentration, C3 Type, and Hemolytic Complement in Sera of Members of the Boe Family

\begin{tabular}{lccc}
\hline \multicolumn{1}{c}{ Subject } & C3 concentration & C3 type & $\mathrm{CH}_{\text {so }}$ \\
\hline & $m g / 100 m l$ & & $U / m l$ \\
Propositus & 132 & fS & 32 \\
Mother & 146 & fS & \\
Wife & 157 & SS & 48 \\
Son 1 & 135 & fS & 34 \\
Son 2 & 144 & SS & 47 \\
Normal range & $97-204$ & & $32-45$ \\
\hline
\end{tabular}

TABLE II

Metabolism of C3 FF-125I and C3 SS-131 I in Subjects of Different C3 Types

\begin{tabular}{|c|c|c|c|c|}
\hline \multirow{2}{*}{$\begin{array}{l}\text { Recipient } \\
\text { C3 type }\end{array}$} & \multirow{2}{*}{$\begin{array}{l}\text { C3 } \\
\text { prepar- } \\
\text { ation }\end{array}$} & \multirow{2}{*}{$\begin{array}{l}\text { Catabolic } \\
\text { rate }\end{array}$} & \multirow{2}{*}{$\begin{array}{l}\text { Allelic } \\
\text { synthesis } \\
\text { rate* }\end{array}$} & \multirow{2}{*}{$\begin{array}{c}\begin{array}{c}\text { Extravascular } \\
\text { pool }\end{array} \\
\text { Plasma pool }\end{array}$} \\
\hline & & & & \\
\hline & & $\begin{array}{c}\text { \% plasma } \\
\text { pool } / h r\end{array}$ & $m g / k g$ per $h r$ & \\
\hline \multirow[t]{2}{*}{ fS } & SS & 1.65 & 0.61 & 0.52 \\
\hline & FF & 1.42 & 0.35 & 0.29 \\
\hline \multirow[t]{2}{*}{ SS } & SS & 1.76 & 0.47 & 0.56 \\
\hline & FF & 1.53 & $(0.41)$ & 0.41 \\
\hline \multirow[t]{2}{*}{ FF } & SS & 1.80 & $(0.43)$ & 0.58 \\
\hline & FF & 1.57 & 0.38 & 0.37 \\
\hline $\begin{array}{l}11 \text { Subjects } \\
\text { of unknown type } \\
\text { (Mean } \pm 2 s D \text { ) }\end{array}$ & - & $1.26-3.36$ & $(0.43-0.95)$ & $0.49-1.31$ \\
\hline
\end{tabular}

* In $\mathrm{C} 3$ homozygous subjects (C3 SS or $\mathrm{C} 3 \mathrm{FF}$ ), it was assumed that each gene produced $\mathrm{C} 3$ at the same rate. Thus, allelic synthesis rates are onehalf those of total C3. The rates in parentheses are "theoretical" since C3 SS subjects produce no C3 FF or vice versa.

Since the serum concentration of $\mathrm{C} 3 \mathrm{f}$ in this family was at least one-half the concentration of $\mathrm{C} 3 \mathrm{~S}$, the total concentration in affected persons was normal, owing to the large range of normal C3 concentration. For similar reasons, the normal hemolytic complement levels were not surprising.

Genes analogous to $\mathrm{C} 3 \mathrm{f}$ are known in other systems. Among the genes controlling the synthesis of haptoglobin, one is associated with a low relative concentration of $\mathrm{Hp} 2$ compared with $\mathrm{Hp} 1$ in heterozygotes and

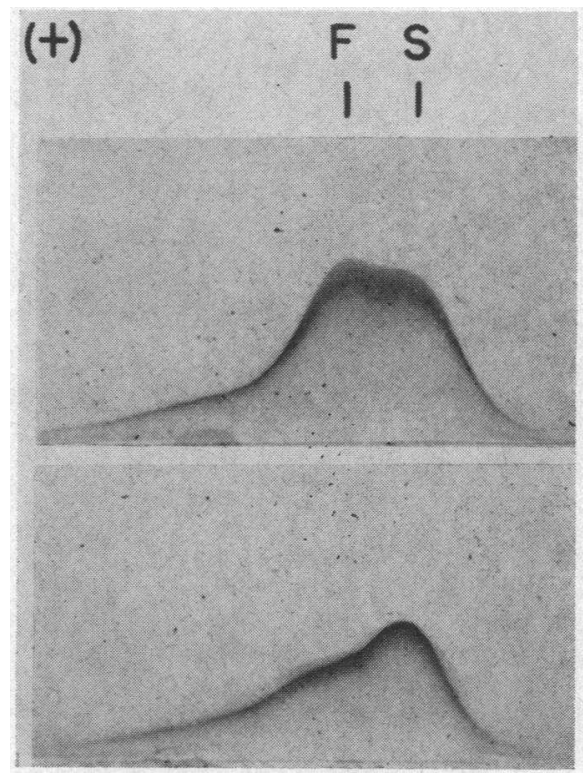

FIGURE 2 Antigen-antibody crossed electrophoresis showing C3 FS (top) and C3 fS (bottom). The positions of C3 F and $\mathrm{C} 3 \mathrm{~S}$ are indicated. The anode for the first separation was at the left and for the second separation was at the top. 
produces the pattern of $\mathrm{Hp} 2-1 \mathrm{M}(14,15)$. Indeed, there appears to be a spectrum of such $\mathrm{Hp}$ alleles (16). Similarly, among the genes controlling $\alpha_{1}$-antitrypsin synthesis, $P i^{\mathrm{P}}, P i^{\mathrm{s}}, P i^{\mathrm{w}}(17)$ and, most notably, $P i^{\mathrm{z}}(18$, $19)$, are associated with low concentration gene products.

The metabolic studies with purified labeled C3 FF and C3 SS suggest, but do not prove, that $C 3^{x}$ is hyposynthetic in comparison with $C 3^{\mathrm{s}}$. Since it is possible that $\mathrm{C} 3 \mathrm{~F}$ and $\mathrm{C} 3 \mathrm{f}$ differ structurally, it would have been more definitive had the metabolism of C3 $\mathrm{f}$ been studied. Unfortunately, it is not yet possible to isolate $\mathrm{C} 3 \mathrm{f}$ from the serum of $\mathrm{C} 3 \mathrm{fS}$ persons and $\mathrm{C} 3 \mathrm{ff}$ has not yet been found. The present studies, therefore, do not rule out the possibility that $\mathrm{C} 3 \mathrm{f}$ is unstable, either at the site of synthesis or in the plasma.

\section{ACKNOWLEDGMENTS}

We thank the Boe family for their cooperation in this study. Mrs. Louise Viehmann performed expert secretarial assistance.

This work was supported by grants from the U. S. Public Health Service (AM 13855, AI 05877, and FR 00128). Dr. Fred Rosen is the recipient of Career Development Award 1-K3-AM-19,650 from the U. S. Public Health Service.

\section{REFERENCES}

1. Alper, C. A., and R. P. Propp. 1967. An electrophoretic variant of human $C^{\prime} 3$. Clin. Res. 15: 291. (Abstr.)

2. Wieme, R. J., and L. Demeulenaere. 1967. Genetically determined electrophoretic variant of the human complement component C'3. Nature (London). 214: 1042.

3. Alper, C. A., and R. P. Propp. 1968. Genetic polymorphism of the third component of human complement $\left(\mathrm{C}^{\prime} 3\right)$. J. Clin. Invest. 47: 2181.

4. Azen, E. A., and O. Smithies. 1968. Genetic polymorphism of $C^{\prime} 3$ ( $\beta_{1 \mathrm{C}}$-globulin) in human serum. Science (Washington). 162: 905
5. Laurell, C.-B. 1966. Quantitative estimation of proteins by electrophoresis in agarose gel containing antibodies. Anal. Biochem. 15: 45.

6. Boyden, A., E. Bolton, and D. Gemeroy. 1947. Precipitin testing with special reference to the photoelectric measurement of turbidity. J. Immunol. 57: 211.

7. Nilsson, U. R., and H. J. Müller-Eberhard. 1965. Iso-

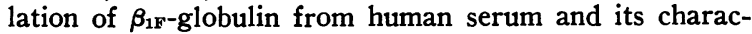
terization as the fifth component of complement. J. Exp. Med. $122: 277$.

8. Laurell, C.-B. and J.-E. Niléhn. 1966. A new type of inherited serum albumin anomaly. J. Clin. Invest. 45: 1935.

9. Wilson, A. T. 1964. Direct immunoelectrophoresis. J. Immunol. 92: 431.

10. Alper, C. A., and A. M. Johnson. 1969. Immunofixation electrophoresis: a technique for the study of protein polymorphism. Vox Sang. 17: 445.

11. Laurell, C.-B. 1965. Antigen-antibody crossed electrophoresis. Anal. Biochem. 10: 358.

12. McFarlane, A. S. 1958. Efficient trace-labelling of proteins with iodine. Nature (London). 182: 53.

13. Alper, C. A., and F. S. Rosen. 1967. Studies of the in vivo behavior of human $\mathrm{C}^{\prime} 3$ in normal subjects and patients. J. Clin. Invest. 46: 2021.

14. Connell, G. E., and O. Smithies. 1959. Human haptoglobins: estimation and purification. Biochem. J. 72: 115.

15. Parker, W. C., and A. G. Bearn. 1963. Control gene mutations in the human haptoglobin system. Nature (London). 198: 107.

16. Sutton, H. E., and G. W. Karp, Jr. 1964. Variations in heterozygous expression at the haptoglobin locus. Amer. J. Hum. Genet. 16: 419.

17. Fagerhol, M. K., and H. E. Hauge. 1969. Serum Pi types in patients with pulmonary diseases. Acta Allergol. 24: 107 .

18. Eriksson, S. 1965. Studies in $\alpha_{1}$-antitrypsin deficiency. Acta Med. Scand. Suppl. 177: 432.

19. Fagerhol, M. K., and C.-B. Laurell. 1967. The polymorphism of "prealbumins" and $\alpha_{1}$-antitrypsin in human sera. Clin. Chim. Acta. 16: 199. 